\title{
乱流予混合火炎で観察される選択拡散の痕跡*
}

\author{
橋 本 英 樹*1, 谷 本隆*2 \\ 古川純 - $^{* 3}$, Forman A. WILLIAMS*4
}

\section{Traces of Preferential Diffusion Observed in Turbulent Premixed Flames}

\author{
Hideki HASHIMOTO*5, Ryu TANIMOTO, \\ Junichi FURUKAWA and Forman A. WILLIAMS \\ ${ }^{* 5}$ Department of Mechanical Engineering Science, Kyushu University, \\ 744 Motooka, Nishi-ku, Fukuoka-shi, Fukuoka, 819-0395 Japan
}

\begin{abstract}
Effect of the preferential diffusion between oxygen and fuel molecules is observed as the cellular flame in laminar premixed flames. When the diffusion coefficient of the deficient species is larger, the deficient species diffuses preferentially to the reaction zone to cause the local stratification of the mixture ratio along the flame. Therefore, the cellular flame is established. If the preferential diffusion should occur in propane-air turbulent premixed flames, the wrinkle scale of rich flames would be smaller than that of lean flames, consequently, the turbulent burning velocity and/or the heat release rate of the former would be larger than those of the latter. Based on these considerations, traces of the preferential diffusion are sought from experimental results of propane-air turbulent premixed flames. Comparing the radius of curvature of the flamelet of rich and lean propane-air flames with the same laminar burning velocity, the radius of curvature of the flamelet of the former are smaller than those of the latter. The gas expansion ratio across the flamelet of the former is larger than that in the latter. The magnitudes of the flamelet velocity vector of the former are larger than the latter.
\end{abstract}

Key Words : Flame, Premixed Combustion, Turbulence, Cellular Flame, Preferential Diffusion

\section{1. 粕 論}

予混合燃焼における燃料分子と酸素分子間の選択拡 散の影響は，層流火炎においてはセル状火炎として比 較的容易に観察することができる. 一方，乱流予混合 火炎において選択拡散が起きていることを明らかにす るためには，火炎反応帯の末然焼混合気に対して凸な 部分と凹な部分で混合気濃度が異なることを計測によ り明らかにしなければならない.しかし，このような 計測を実現することは殆ど不可能に近く，乱流予混合 火炎における選択拡散の影響は, 層流予混合火炎で起 きる現象に基づいた定性的な議論の域を脱していない.

しかし，これまでに乱流予混合火炎において得られ た実験結果には，選択拡散の影響であると考えられる 結果が数多く見られる.

* 原稿受付 2009 年 3 月 2 日.

*1 正員, 九州大学大学院工学研究院 ( 819-0395 福岡市西区 元岡 744)

*2 学生員, 東京都立産業技術高等専門学校専攻科 (《) 140-0011 東京都品川区東大井 1-10-40).

*3 正員, 東京都立虐業技術高等専門学校ものづくり工学科 (正 140-0011 東京都品川区東大井 1-10-40).

${ }^{* 4}$ University of California (9500 Gilman Dr., La Jolla, CA 92093, USA).

E-mail : hashimoto@mech.kyushu-u.ac.jp
そこで本論文では，これまでに乱流予混合火炎にお いて得られた実験結果に見られる選択拡散の痕跡をま とめてみた.

\section{2. 予湦合火炎における選択拡散}

先に述べたように，層流子混合火炎では燃料分子と 酸素分子間の選択拡散により自発的にセル状火炎が形 成される. 燃料分子亡酸素分子のうち拡散係数の大き な化学種が不足している場合, 不足している化学種が 火炎反応帯に選択的に拡散し，局所的に混合比の不均 一が起きることに起因している ${ }^{(1)}$.

例えばプロパン・空気予混合火炎では，酸素の拡散 係数はプロパンの拡散係数より大きく，図 1 に示すよ うに火炎面の未燃焼混合気に対して凸な部分には拡散 しやすい酸素が集中し，逆に火炎面の燃焼ガスに対し て凸な部分には拡散しにくいプロパンが集まる。した がって，過濃混合気では混合気中の不足成分である酸 素が火炎面の未燃焼混合気に対して凸な部分に選択的 に拡散し，その部分では酸素濃度が増加することによ り局所的な燃焼速度が増加する. その結果, セル状火 炎が形成される (2)。 


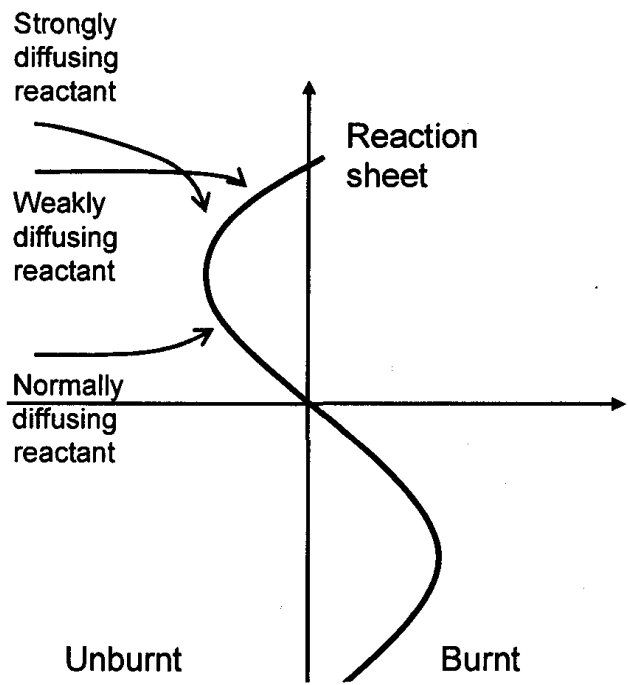

Fig. 1 Schematic illustration of the mechanism of preferential diffusion

一方，乱流予混合火炎における選択拡散の影響は層 流予混合火炎ほど明確ではない，乱流予混合火炎にお ける選択拡散の影響に関する最初の文献は, 恐らく Palm-Leis と Strehlow の論文 ${ }^{(3)}$ であろう. 彼らは瞬間 シュリーレン写真を用いてプロパン・空気混合気中を 伝播する乱流火炎の観察を行い，燃料過濃側で火炎面 の凹凸のスケールが小さくなることを見出し，この現 象は燃料分子と酸素分子間の選択拡散の効果によるも のと考えた.

Palm-Leis と Strehlow の報告以降も, 乱流予混合火炎 において選択拡散の効果であると考えられる結果が得 られている ${ }^{(4)} \sim(7)$ が, それらの多くは定性的な結果 ${ }^{(4)}$, (5) であり，定量的な結果を報告した研究 ${ }^{(6),(7)}$ は少 なく, 乱流予混合火炎における選択拡散の影響は十分 に明らかにされたとは言えない.

ところで，大きなスケールの比較的弱い乱流場にお ける乱流予混合火炎では, 火炎面に凹凸の変形が生じ, その結果, 火炎面の面積が増加する. この場合, 瞬間 的に見た火炎は分子輸送過程に支配され，局所的には 層流燃焼速度で伝ぱする凹凸のある層流予混合火炎で あり, 平均の燃焼速度, すなわち乱流燃焼速度は火炎 面の面積に比例すると考えられている。 したがって, 火炎面の凹凸のスケールを定量的に評価することが乱 流燃焼速度を評価する上で本質的な問題となる。

乱流予混合火炎の火炎面の凹凸のスケールは混合気 の乱流特性および流体力学的な不安定性, セル状不安 定性などの火炎の固有不安定性に依存すると考えられ る ${ }^{(1)}$.これらのうち, 流体力学的不安定性の影響は大 気圧下では顕著には見られず，高圧下でのみ観察でき るため ${ }^{(8)}$, 乱流予混合火炎の火炎面の凹凸のスケール
は混合気の乱流特性およびセル状不安定性に依存する と考えて良い.

\section{3. 乱流予混合火炎における選択拡散の痕跡}

このような観点に立脚し, 先の研究 ${ }^{(9),(10)}$ では, 非 燃焼時の流れが等しく混合気の乱流特性が等しい条件 で, 層流燃焼速度が最大となる量論比付近と燃料希薄 側と過濃側で層流燃焼速度が等しい混合気濃度のプロ パン・空気およびメタン・空気乱流予混合火炎の火炎 面の曲率半径を調べた. これらの結果を図 2 および図 3 に示す.ここでは, 同一の乱れの条件の下で層流燃 焼速度の等しい燃料希薄側と過濃側で火炎面の凹凸の スケールを比較することにより，火炎面の凹凸のスケ

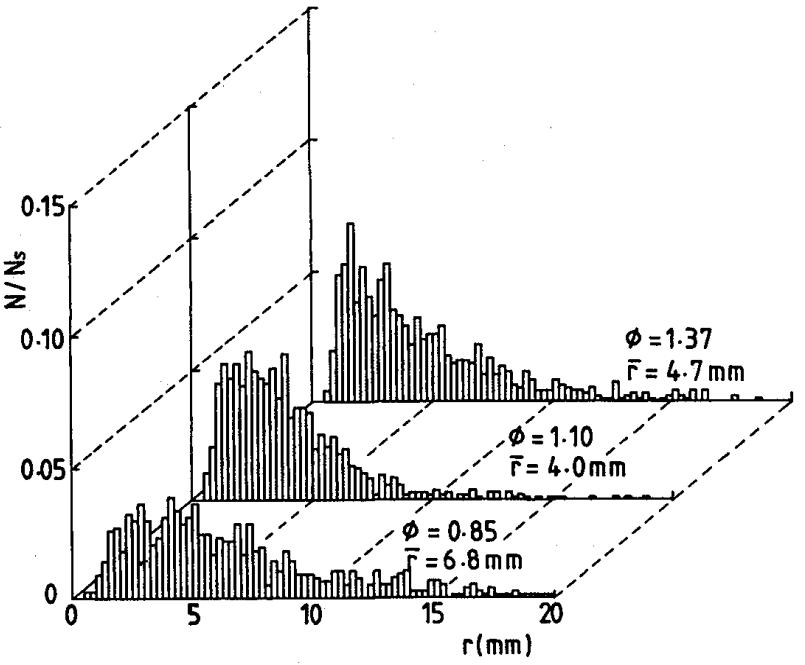

Fig. 2 Frequency distribution of the radii $r$ of the flamelet curvature convex toward unburnt mixture for propane-air flames, $N$ : Numbers of $r$ in each $0.25 \mathrm{~mm}$ bin, $N s$ : Sample size

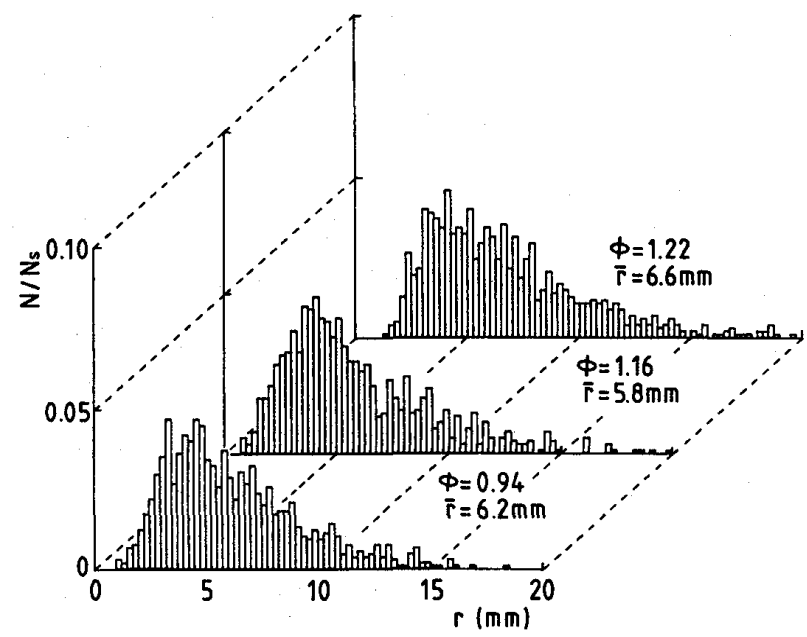

Fig. 3 Frequency distribution of the radii $r$ of the flamelet curvature convex toward unburnt mixture for methane-air flames, $N$ : Numbers of $r$ in each $0.25 \mathrm{~mm}$ bin, $N s$ : Sample size 
一ルに及ぼすセル状不安定性の影響を調べることがで きると考えた。

プロパン・空気乱流予混合火炎では, 希薄火炎に比 ベて過濃火炎における火炎面の未燃焼混合気に凸な部 分の曲率半径は小さい, 一方, メタン火炎では, 希薄, 過濃火炎における火炎面の未燃焼混合気に凸な部分の 曲率半径に有意差はみられない。

最大成分である窒素に対する二成分拡散係数を考え た場合，プロパンの拡散係数は酸素の拡散係数のおよ そ 1/2 程度である.したがって,プロパン・空気混合 気中では，過濃混合気において乱れにより誘起された 火炎面の凹凸の未燃焼混合気側に凸な部分が不足成分 である酸素の選択拡散を助長するはずである．その場 合, 火炎面の未燃焼混合気側に凸な部分の酸素濃度が 増加し, 燃料と酸化剂の局所的な混合比が量論比に近 づき, 局所的な燃焼速度が増加するはずである. また， 局所的な燃焼速度の増加により，火炎面の未燃焼混合 気側に凸な部分は未燃焼混合気に向かってさらに伝播 し，火炎面の未燃焼混合気側に凸な部分の湾曲を助長 するはずである。この局所的な燃焼速度の増加による 火炎面の湾曲は，乱流中のひずみが火炎面を平坦化す る効果と釣合うまで進行する ${ }^{(1)}$. そのため, 過濃プロ パン火炎では選択拡散の影響により，火炎面の末燃焼 混合気側に凸な部分と燃焼ガス側に凸な部分で混合気 の組成に変化が生じるだけでなく，火炎面の凹凸のス ケールに変化が現れたと考えられる.

一方, メタンの拡散係数は酸素の拡散係数とほぼ等 しく, 両者の拡散速度はほぼ等しいと考えられるので, メタン火炎においては選択拡散の効果は現れないと考 えられる.

また，過濃プロパン火炎では選択拡散により乱流然 焼速度が増加すると報告 ${ }^{(4)}$ されている. 乱流燃焼速度 の計測はそれほど容易なことではないが，火炎面の凹 凸のスケールが小さくなれば火炎面の表面積が増加し, 乱流燃焼速度も増加するはずである.

ところで, 層流燃焼速度は角度法, 面積法など ${ }^{(1)}$ で比較的容易に計測することができるが，乱流燃焼速 度を計測することはそれ程容易ではない，角度法，面 積法いずれの手法を使うにしても, 火炎面の位置を決 定する一般的な合意がないこと, 乱流火炎帯で火炎面 の凹凸のスケールが場所により異なることなどがその 理由である. 特に後者は乱流燃焼速度が一様ではなく， もはや乱流燃焼速度という概念が成立しないことを示 している.

先の研究 ${ }^{(12)}$ では, 乱流燃焼速度が大きければ火炎 面の移動速度も大きくなるはずと考え，火炎面の移動
速度を比較してみた。ここでは，同一の乱れの条件の 下で層流然焼速度の等しい燃料希薄側と過濃側で火炎 面の移動速度を比較することにより，火炎面の移動速 度に及ぼすセル状不安定性の影響を調べることができ ると考えた．同一の計測位置におけるプロパンおよび メタン火炎の火炎面の移動速度の確率分布をそれぞれ 図 4 および図 5 に示す。

過濃プロパン火炎に拉ける火炎面の移動速度は希薄 プロパン火炎に比べ明らかに大きい. 一方, 希薄, 過 濃メタン火炎における火炎面の移動速度には有意差は 見られない，非然焼時の流れが等しく，層流燃燒速度 もほぼ等しい条件において, 火炎面の平均的な移動速 度が大きいことは乱流燃焼速度が大きいことを示して いると考えられる. 寸なわち，過濃プロパン火炎では 他の条件に比べ, 乱流燃焼速度が大きいと考えられる.

乱流燃焼速度が増加するメカニズムに関しては 理論的な研究も多く行われており，例えばClavin とWilliams ${ }^{(13)}$ は弱い乱れによる燃焼促進効果を報 告している. しかし，彼らの報告する火炎におけ る乱れの燃焼促進は希薄火炎, 過濃火炎ともに同 様であり，乱れの燃焼促進効果には希薄火炎，過 濃火炎による差は見られない，乱れの燃焼促進に 関する理論的な解析の多くは乱れの強い火炎を対
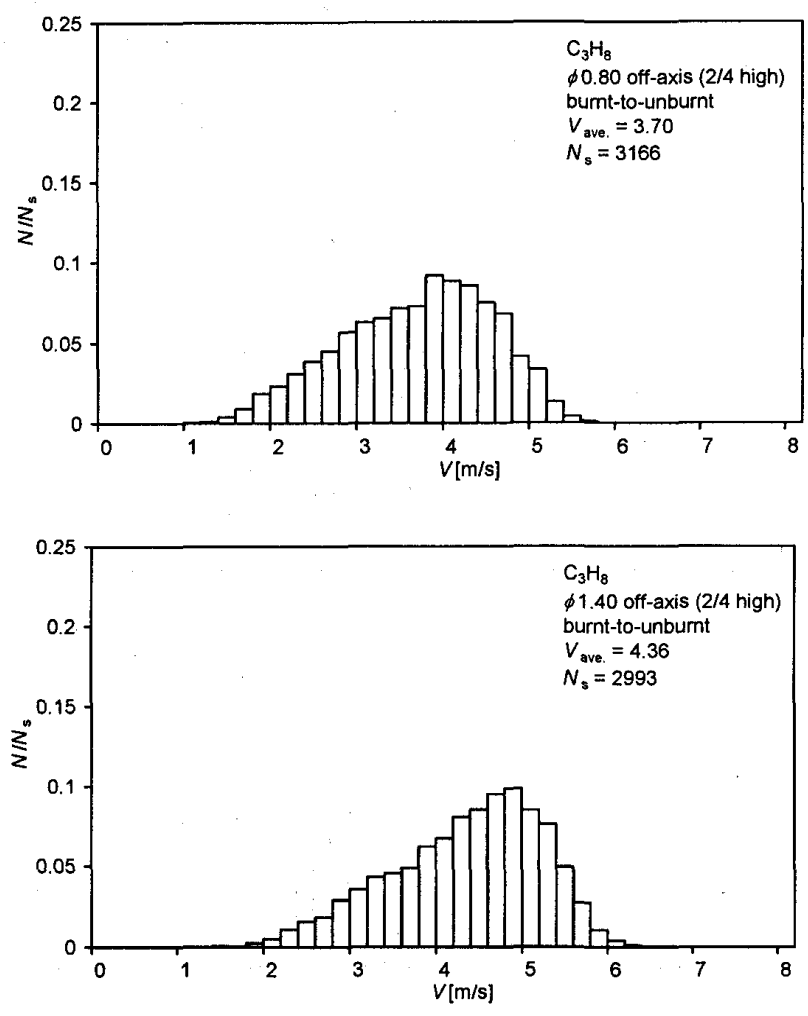

Fig. 4 Probability distribution of magnitude of the flamelet velocity of propane flame for $\phi=0.80$ (upper) and $\phi=1.40$ (lower) 
象としており ${ }^{(14) \sim(16)}$, 先の結果の妥当性を直接検 証するための従来研究は現在のところ見当たらな い. しかし, Clavin と Williams ${ }^{(13)}$ が示すように, 選択拡散の影響がない火炎における乱れの燃焼促 進効果には希薄火炎, 過濃火炎による差はなく, 過濃プロパン火炎における乱流燃焼速度の増加には 選択拡散が重要な役割を果たしていると考えられ る.

先の研究では ${ }^{(17)}$ は同一の乱れの条件の下で層流然 焼速度の等しい希薄および過濃プロパン火炎にお ける乱れの変化を調へ，図 6 および図 7 に示すよ うに，両者の火炎では火炎面の前後における乱れ の増幅率が異なることを明らかにした．乱れのパワ 一スペクトル密度関数は, 希薄火炎に比べ過濃火炎 においてバーナ軸方向およびバーナ半径方向とも に大きく，乱れの増幅が著しいことが明瞭である。 すなわち，これらの結果は希薄プロパン火炎に比べ 過濃プロパン火炎では，乱流火炎帯における熱膨 張が大きいことを示している．酸素の選択拡散が 助長され，局所的な燃焼速度が増加すれば，乱流 火炎帯における発熱量が増加し，熱膨張も大きく なるはずである。
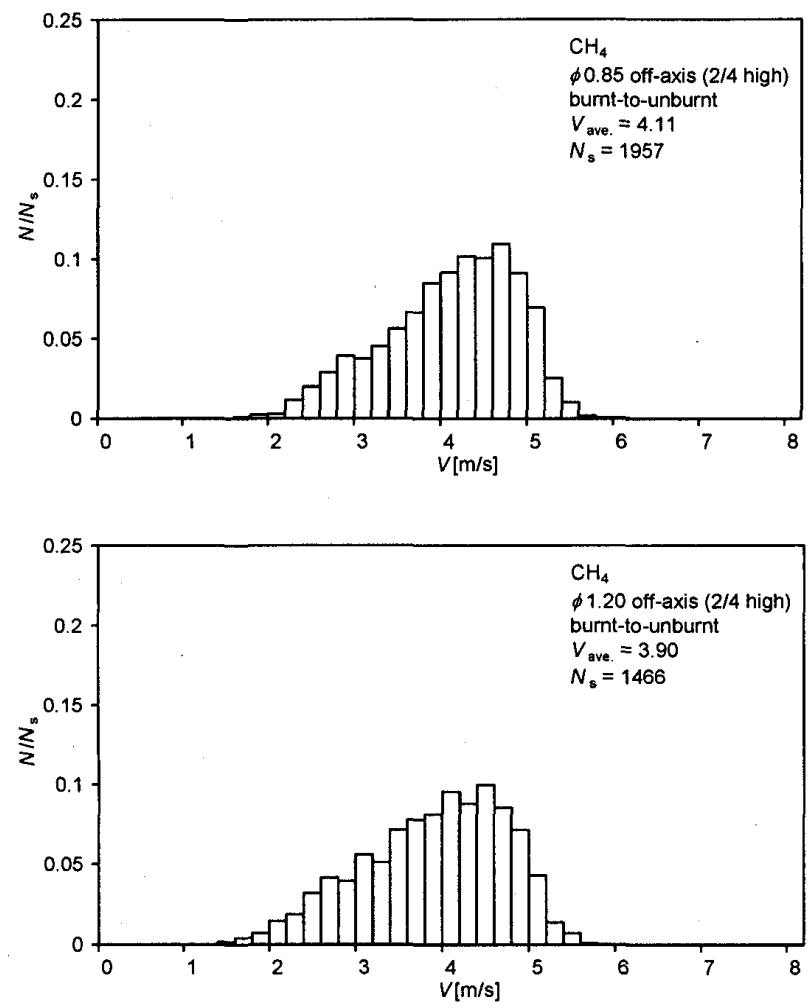

Fig. 5 Probability distribution of magnitude of the flamelet velocity of methane flame for $\phi=0.85$ (upper) and $\phi=1.20$ (lower)
さらに，先の報告 ${ }^{(12),(18)}$ では，過濃プロパン火 炎の火炎面の三次元挙動は希薄プロパン火炎およ び希薄，過濃メタン火炎とは異なることを明らか にした，希薄および過濃プロパン火炎における火 炎面の速度べクトルの水平面上への射影を図 8 および 図 9 に示す. 図の左側 ( $\mathrm{x}$ 軸の負の側)にバー十中心軸

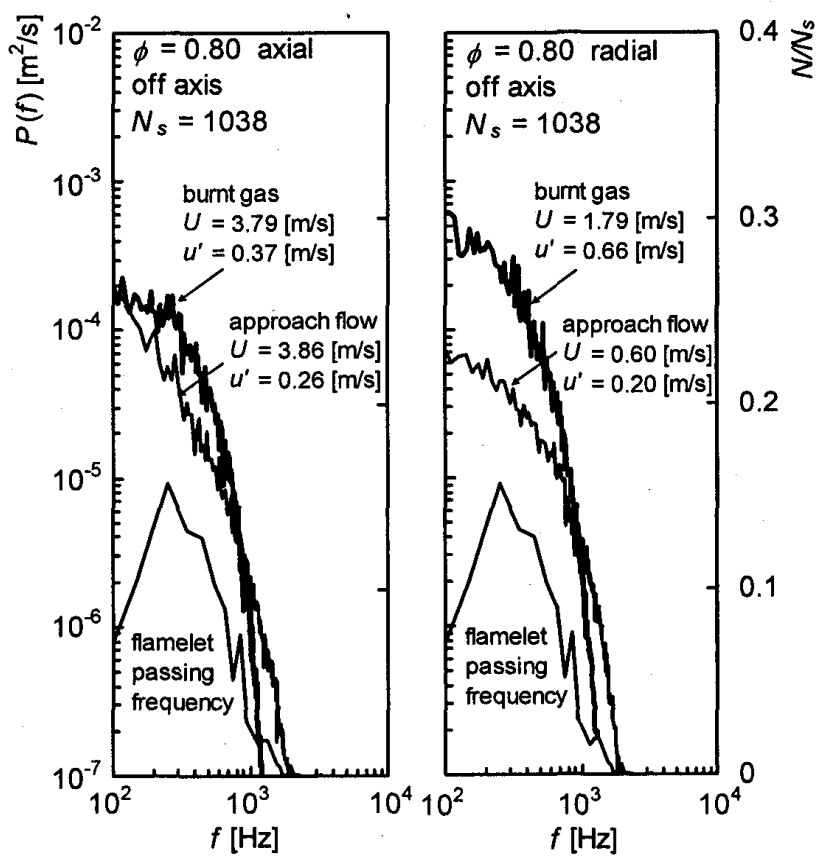

Fig. 6 Change of the power-spectrum density function across the flamelet of the propane-air flame for $\phi=0.80$ at the off-axis position

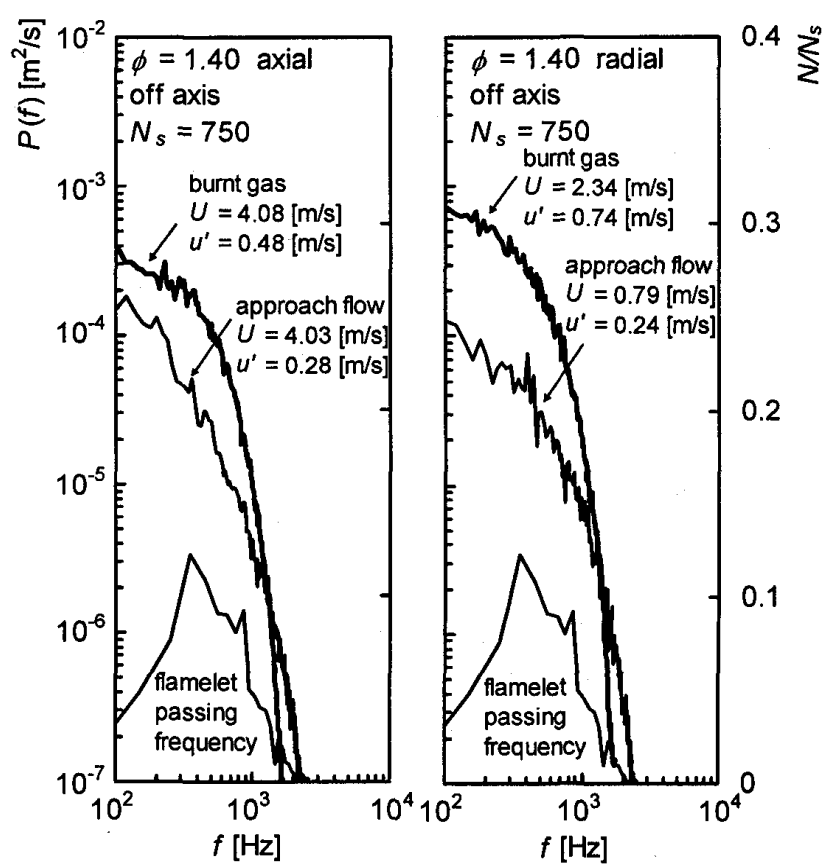

Fig. 7 Change of the power-spectrum density function across the flamelet of the propane-air flame for $\phi=1.40$ at the off-axis position 
は位置する，なお，両者はほぼ同様の計測位置にお ける結果であり, 希薄, 過濃メタン火炎と希薄プ ロパン火炎の火炎面の三次元挙動には有意差は見 られなかった。

希薄プロパン火炎および希薄, 過濃メタン火炎 では，未燃焼混合気側に移動する火炎面はバーナ 中心軸側に偏向して移動し，燃焼ガス側に移動す る火炎面はバーナ外側に偏向して移動する。しか し, 過濃プロパン火炎では, 未燃焼混合気側, 燃 焼ガス側に移動する火炎面ともにバーナ外側に偏
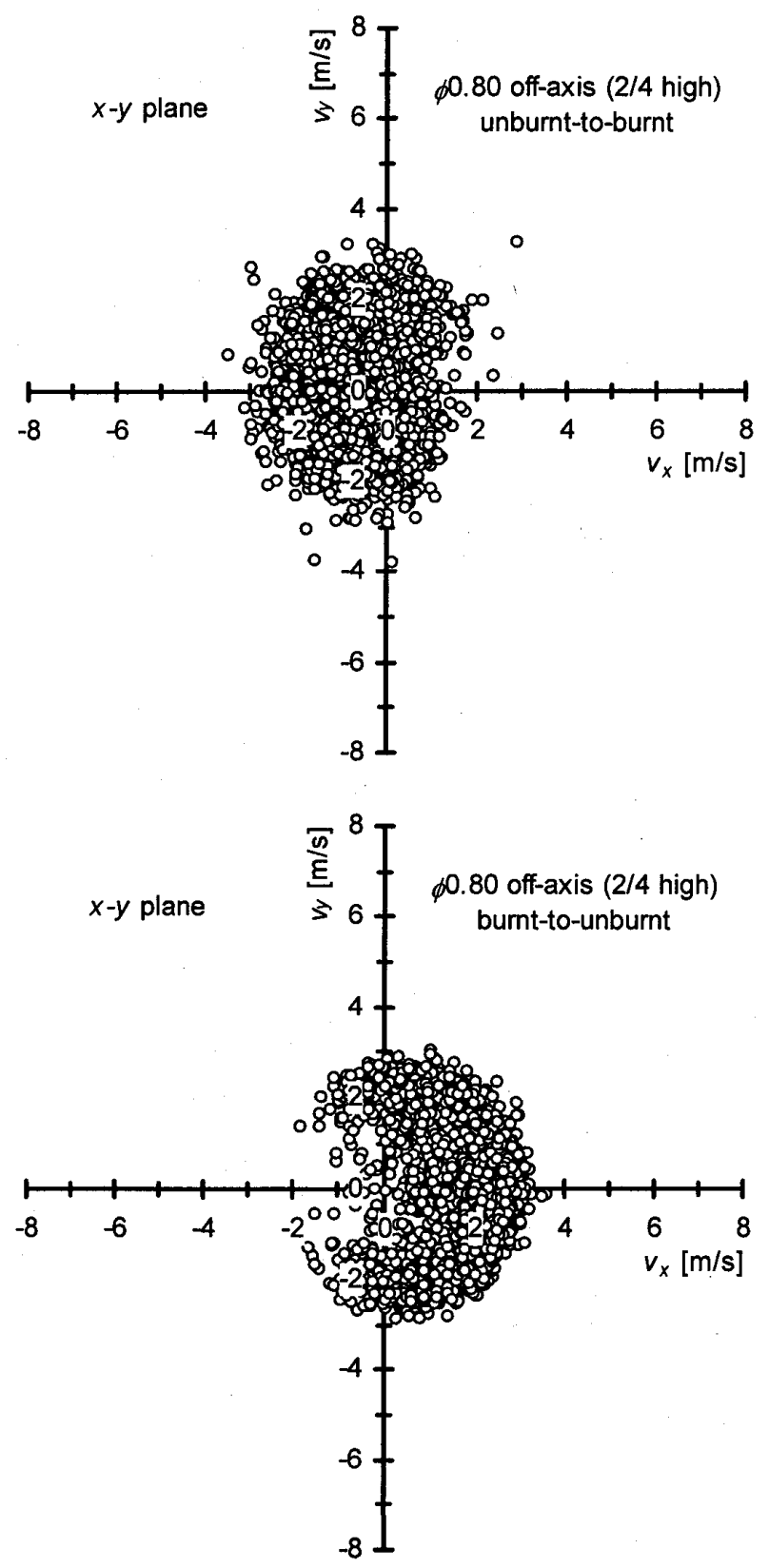

Fig. 8 Vector distribution map of the flame-front movement on the $x-y$ plane in the unburnt-to-burnt (upper) and burnt-to-unburnt (lower) directions at the off-axis for $\phi=0.80$
向して移動する，先述の通り，過濃プロパン火炎 では希薄プロパン火炎に比べ乱流火炎帯における 熱膨張が大きい，乱流火炎帯における熱膨張の増 大により，流れは拡がる(flow divergence)はずであ る.したがって，過濃プロパン火炎においてのみ 観察された特異な火炎面の挙動は，熱膨張の増大 に起因する flow divergenceによるものと考えられ る.

以上のように，これまでに乱流予混合火炎におい て得られた実験結果には，選択拡散の影響であると考
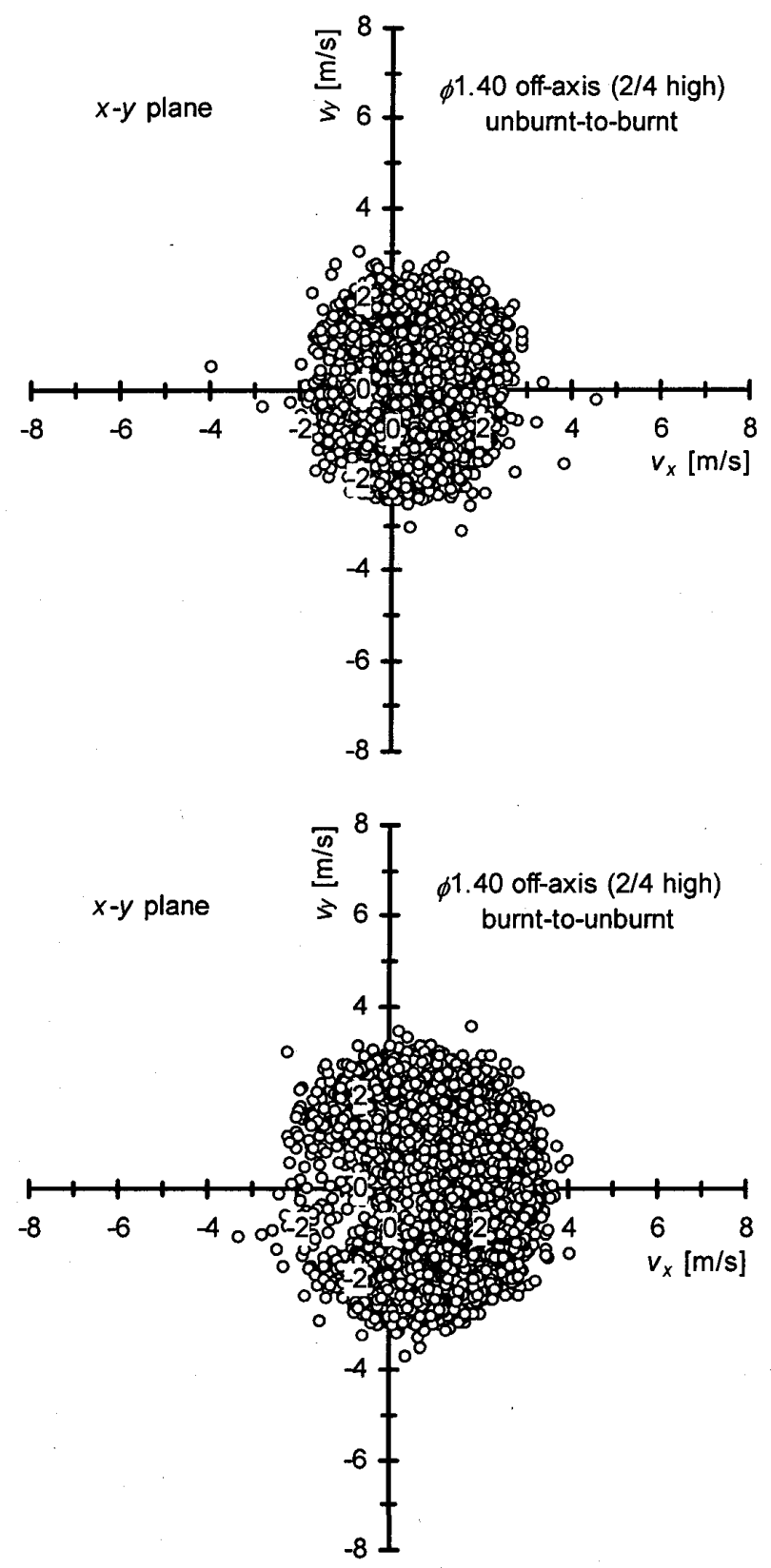

Fig. 9 Vector distribution map of the flame-front movement on the $x-y$ plane in the unburnt-to-burnt (upper) and burnt-to-unburnt (lower) directions at the off-axis for $\phi=1.40$ 
えられる結果が数多く見られた. 過濃なプロパン・空 気乱流予混合火炎においては, 乱れにより誘起された 火炎面の凹凸のうち，未然焼混合気側に凸な部分の曲 率半径が小さい，そのため，末燃焼混合気側に凸な部 分の火炎面では, 燃料分子と酸素分子のうち拡散係数 の大きい酸素分子が不足しているために, 酸素の選択 的な拡散が助長される. その結果, その部分における 酸素濃度が増加し, 局所的な燃焼速度が増加する. さ らに局所的な燃焼速度の増加により, 発熱に伴う熱膨 張が増大し，流れが拡がるために，未然焼混合気およ び燃焼ガス側に移動する火炎面ともにバーナ外側に偏 向して移動する.

このように乱流予混合火炎における選択拡散は, 乱 れにより誘起された火炎面のしわによって局所的な混 合比に変化を生じ，この組成変化によって火炎温度は 変化し, 局所的な燃焼速度も変わるため, 火炎面の形 状や動きに影響を与えると考えられる。

\section{4. 結}

本論文では, これまでに乱流予混合火炎において得 られた実験結果に見られる選択拡散の痕跡をまとめて みた。

過濃なプロパン・空気乱流予混合火炎においては, 乱れにより誘起された火炎面の凹凸のうち，未然焼混 合気側に凸な部分の曲率半径が小さい，そのため，未 燃焼混合気側に凸な部分の火炎面では, 燃料分子と酸 素分子のうち拡散係数の大きい酸素分子が不足してい るために, 酸素の選択的な拡散が助長される. その結 果, その部分における酸素濃度が増加し, 局所的な燃 焼速度が増加する. さらに, 局所的な燃焼速度の増加 により発熱に伴う熱膨張が増大し，流れが拡がるため に，未燃焼混合気および然焼ガス側に移動する火炎面 ともにバーナ外側に偏向して移動する.

以上のようにこれまでに得られた実験結果より, 乱 流予混合燃焼における選択拡散の影響が現れるメカニ ズムを少なからず明確にできたと考える.

\section{文献}

(1) Williams F. A., Combustion Theory 2nd Ed.,(1985), pp. 341-365, Addison Wesley.

(2) Markstein G. H., Experimental and Theoretical Studies of Flame-Front Stability, Journal of Aeronautical Science, Vol.18 (1951), pp. 199-209.

(3) Palm-Leis A. and Strehlow R. A., On the Propagation of Turbulent Flames, Combustion and Flame, Vol. 13 (1969), pp. 111-129.

(4) Kido H., Nakahara M., Nakashima K. and Hashimoto J., Influence of Local Flame Displacement Velocity on Turbulent Burning Velocity, Proceedings of Combustion Institute, Vol. 29 (2002), pp. 1855-1861.

(5) Tsuruda T. and Hirano T., Local Flame Front Disturbance Development under Acceleration, Combustion and Flame, Vol.84 (1991), pp. 66-72.

(6) Furukawa J. and Hirano T., Laminarization of a Turbulent Flame Approaching to a Solid Wall, Combustion Science and Technology (Japanese edition), Vol. 1, No. 4 (1994), pp. 283-291.

(7) Wu M. S., Kwon S., Driscoll J. F. and Faeth G. M., Preferential Diffusion Effects on the Surface Structure of Turbulent Premixed Hydrogen/Air Flames, Combustion Science and Technology, Vol. 78 (1991), pp. 69-96.

(8) Kobayashi H. and Kawazoe H., Flame Instability Effects on the Smallest Wrinkling Scale and Burning Velocity of High-Pressure Turbulent Premixed Flames, Proceedings of the Combustion Institute, Vol. 28 (2000), pp. 375-382.

(9) Furukawa J., Maruta K. and Hirano T., Flame Front Configuration of Turbulent Premixed Flames, Combustion and Flame, Vol. 112 (1998), pp. 293-301.

(10) Furukawa J., Okamoto K., Ishizawa S., Gomi T. and Hirano T., Transport Mechanism at the Local Reaction Zone of Small-Scale and High-Intensity Turbulent Premixed Flame, Transaction of the Japan Society of Mechanical Engineers, Series B, Vol. 62, No. 598 (1996), pp. 2460-2465.

(11) Hirano T., Combustion - Combustion Phenomenon and its Control - (in Japanese), (1986), pp. 51, Kaibundo Publishing Co., Ltd.

(12) Hashimoto H., Sou A., Tomiyama A., Furukawa J. and Williams F. A., Flamelet Movements in Lean and Rich Methane-air and Propane-air Turbulent Premixed Flames, Transaction of the Japan Society of Mechanical Engineers, Series B, Vol. 74, No. 744 (2008), pp. 1835-1842.

(13) Clavin P. and Williams F. A., Theory of Premixed-flame Propagation in Large-scale Turbulence, Journal of Fluid Mechanics, Vol. 90 (1979), pp. 589-604.

(14) Libby P. A., Peters N. and Williams F. A., Cylindrical Premixed Laminar Flames, Combustion and Flame, Vol. 75 (1989), pp. 265-280.

(15) Peters N. and Williams F. A., Premixed Combustion in a Vortex, Twenty-Second Symposium (International) on Combustion, (1988), pp. 495-503.

(16) Asato K., Wada H., Hiruma T. and Takeuchi Y., Characteristics of Flame Propagation in a Vortex Core: Validity of a Model for Flame Propagation, Combustion and Flame, Vol. 110 (1997), pp. 418-428.

(17) Furukawa J., Noguchi Y., Hirano T. and Williams F. A., Anisotropic Enhancement of Turbulence in Large-scale, Low-intensity Turbulent Premixed Flames, Journal of Fluid Mechanics, Vol. 462 (2002), pp. 209-243.

(18) Hashimoto H., Furukawa J., Okamoto K. and Williams F. A., 3-D Movement of Flame Fronts in Propane-Air Turbulent Premixed Flame, Part II: Flame-Front Movement at the Off-axis, Transaction of the Japan Society of Mechanical Engineers, Series $B$, Vol. 74, No. 740 (2008), pp. 936-941. 